\title{
Katı Atık Yönetiminde Kompostlaştırmanın Önemi, Problemler ve Çözüm Önerileri: Türkiye Örneği
}

\author{
Gürdal Kanat ${ }^{1}$, Gökhan Önder Ergüven ${ }^{2 *}$ \\ ${ }^{1}$ Yildiz Technical University, Faculty of Civil Engineering, Environmental Engineering Department, Istanbul, Turkey (ORCID: 0000-0003-2600-2912) \\ ${ }^{2}$ Munzur University, Tunceli Vocational School, Department of Chemistry and Chemical Process Technologies, Laboratory Technology Pr, Tunceli, Turkey \\ (ORCID: orcid.org/0000-0003-1573-080X)
}

(İlk Geliş Tarihi 9 Ocak 2020 ve Kabul Tarihi 23 Mayıs 2020)

(DOI: 10.31590/ejosat.672413)

ATIF/REFERENCE: Kanat, G. \& Ergüven, G. Ö. (2020). Importance of Solid Waste Management on Composting, Problems and Proposed Solutions: The Case of Turkey. Avrupa Bilim ve Teknoloji Dergisi, (19), 66-71.

\section{Öz}

Organik atıkların yüksek üretim oranları ve bu atıkların açık çöp sahalarına veya sıhhi olmayan depolama alanlarına atılması olumsuz birtakım çevresel, ekonomik ve sosyal sorunlara neden olmaktadır. Kompostlama, organik atıkların yönlendirilmesinde daha temiz teknolojilerden birini temsil eder. Elde edinilen son raporlara göre, Türkiye'de 2018 yılında üretilen belediye atık miktarı 32,2 milyon ton olarak gerçekleşti. Diğer ülkelere benzer şekilde, Türkiye'de belediye atıklarının en uygun ve ekonomik yöntemlerle bertaraf edilmesi planlanmaktadır. Belediye atık yönetimi planlaması yönetmeliklerin amaçlarına dayanmaktadır. Mevcut durumda, Çevre Bakanlığı verilerine göre Türkiye'de 8 adet biyolojik atık işleme tesisi bulunmaktadır. Ayrıca, karışık belediye atıklarının işlendiği 6 mekanik-biyolojik ön arıtma ve geri dönüşüm tesisi bulunmaktadır. Atık yönetim planlarında, 2023 yılında oluşan atıkların \%65'i düzenli depolama ve \%35'i geri kazanımı hedeflenmiştir. Bu çalışmada, Türkiye ve diğer benzer ülkelerdeki belediye atık yönetimi sorunlarının detayları ve başarı öyküleri incelenmiş ve bunlara ilave olarak sonuçlar tartışılmıştır. Kompostlamanın birçok ülke ve Türkiye'de, bazı sorunlarından dolayı hala yaygın bir yöntem olmadığı görülmektedir. İdari ve teknik faktörler değerlendirildiğinde, atık transferi ile düzenli depolama ve biyogaz geri kazanımı ülkedeki en iyi, en kolay ve ekonomik yöntemdir. Biyolojik ve katı atık yönetimi oldukça önemli bir iştir. Bu proses yönetim sistemi için önemli bir rol oynar. Buna ilave olarak Türkiye'deki ve özellikle İstanbul ilindeki ulusal sıfır atık faaliyetleri ile ilgili yönetim ilk aşamadadır ve bu işlemlerin daha iyi sonuç almaları için uzun bir zaman periyoduna ihtiyacı olduğu aşıkardır.

\section{Importance of Solid Waste Management on Composting, Problems and Proposed Solutions: The Case of Turkey}

\begin{abstract}
The high generation rates of organic waste and their open dumpsite in landfills are resulting in some adverse affects related with environment, economy and social life. Composting represents one of cleaner technologies in diverting organic pollutants from landfill. According to the recent statistics, the amount rate of municipal waste generated in Turkey in 2018 was nearly 32.2 tons. Comparable to the other countries waste management systems, it is a fore thought to arrange of municipal wastes in Turkey with the

\footnotetext{
${ }^{1}$ Corresponding author: Munzur University, Tunceli Vocational School, Department Of Chemistry and Chemical Process Technologies, Laboratory Technology Pr, Tunceli, Turkey, ORCID: 0000-0003-1573-080X, gokhanondererguven@,gmail.com
} 
most suitable and economical methods. Municipal waste management technologies asnd strategies was based on the objectives of the Waste Landfill Regulation and Packaging Wastes Control Regulation. In the recent case, there are 8 biological waste treatment processing facilities in Turkey. Additionally, there are 6 mechanical-biological pre-treatment and recycling process facilities where mixed municipal waste is treated. In the management strategies, the waste formed in 2023 was targeted to $65 \%$ landfilled and $35 \%$ recovery. In this case study, details of municipal waste problems and achievment scenarios in Turkey and in other similar countries are been examined and results are discussed. It is seen that composting is still not a common method in the cities of many countries and Turkey due to some significiant problems. When administrative and technical factors are evaluated, waste transferring to landfill and biogas recovery is the best, easiest and economical method in the country. It is understood that biological and solid waste management is a very important work. This process play a significiant role for management system. Additionally, managements about national zero waste activities in Turkey and especially Istanbul city are still in the first step and this process need long time period to have better results.

Keywords: Composting, developing countries, landfill, municipal waste, management.

\section{Introducion}

Municipal Solid Waste (MSW) is an unavoidable waste, especially in the big cities, related to population increase, (chaotic) urbanization and socio-economic development. MSW management is a serious problem for local and national authorities. MSW is not only contain high amount of organics but also most heterogeneous kind of refuse. Appropriate waste management is crucial for environmental and human health concerns.

Organics generally includes $40-70 \%$ of MSW. Management of the organic fraction of MSW has getting increasing attention. It is also important to separate organic material from the waste stream, by either source separation or centralized mechanical separation, for further treatment, such as composting.

If MSW is disposed improperly, it leads to severe water pollution. MSW can contain not only biological and chemical materials but even some radioactive substances. Moreover, pathogens and heavy metals can leach out and result in water pollution. Composting is an effective method to decompose and treat organic residues such as agricultural waste and sludge (Wang et al., 2017). Additionally, biogas residues could be further treated by composting to stabilize the remaining organic matterials and inhibit pathogens that may survive after anaerobic digestion step. Therefore, the resulting compost may be used to fertilize land, thus ensuring that crops receive most of the essential nutrients required for development. At present, extensive research on biogas residues composting is ongoing.

Composting is used to fertilize and amend soil organically and safely, so it must first be non-toxic and then supply nutrients and structure to soil and plants. So, the parameter of maturity is often used to evaluate the stability and safety of compost. Therefore, evaluation the quality of large-scale composting is urgently needed. Composting is often tested using single-factor index such as temperature, $\mathrm{NH}_{4}^{+}-\mathrm{N}, \mathrm{NO}_{3}^{-}-\mathrm{N}$, nitrification index, cation exchange capacity, and germination (Xiao et al., 2017). While those indexes can describe compost maturity to some extent, the raw materials used for composting are complex, so single-factor index is not comprehensive indicators of compost maturity (Meng et al., 2019).

The Member States of the European Union (EU) have the obligation to implement waste management systems in accordance with the hierarchy of options in the following order of priority: prevention, recycling, reuse, other types of recovery (such as energy), and final disposal (EU, 2008).

In addition, the removal of biodegradable organic matter to the landfill site should be removed gradually. However, despite improved legislation and regulatory systems, public acceptance of new waste disposal and treatment facilities is still very low due to negative impacts on the environment and human health. In this situation, sustainable MSW management requires support through appropriate environmental assessment methods that assess environmental applicability of waste management strategies. The European Commission require greater use of Life Cycle Thought to complete the waste hierarchy.

According to the recent statistic, the amount rate of municipal waste generated in Turkey in 2018 was nearly 32.2 tons. Municipal waste management techlonogies and strategies in Turkey was based on the objectives of the Waste Landfill Regulation and Packaging Wastes Control Regulation. In the management strategies, the waste formed in 2023 was targeted to $65 \%$ landfilled and $35 \%$ recovery. In this case study, details of municipal waste problems and achievment scenarios in Turkey and in other similar countries, especially in composting, are been examined and results are discussed.

\section{Material and Method}

\subsection{Methodology}

The methodology of the study followed to achieve a case study analysis of selected countries and composting applications and reasons of failure in Turkey. The UK, USA, Japan, and China were selected for the case study given their geographical, socioeconomic, waste composition, and waste management profiles. 


\subsection{Biological Solid Waste Management}

MSW is mainly composed of kitchen and garden wastes and its composting has been used by some municipalities. MSW composting is seen as a method of directing organic waste materials from landfills to a product that is suitable for agricultural purposes in a relatively low cost way (Laurent et al. 2014). However, the uncertainties of this process are as follows - it is a slow process and separation of solid wastes is difficult. Therefore, this process is not very efficient.

In recent years, compost has been extensively studied for soil remediation and described as the most suitable material for the removal of pollutants. Composting has been proposed as an effective method to minimize landfill impact (Mohee and Soobhany 2014; Mohammadshirazi et al., 2016; Logsdon et al., 2017). Composting is generally done as aerobic biological treatment and results in a biostabilized product. The degree of impact depends on the level of stability achieved. However, during the composting process, some environmental problems, including the formation of malicious or toxic gases and bioerosols may occur and may cause occupational health risks or discomfort to nearby people (Wei et al. 2017; Pearson et al. 2015). Composting is known to have some health problems such as biological and chemical risks, endotoxins, parasitic protozoa or volatile organic compounds (VOCs). These problems, however, are mainly in or around plants. In addition, compost can provide heavy metal concentrations of the waste in soil.

Related to composting, odor attracted great attention due to their significant impact on the life quality. Taiwan Environmental Protection Administration legislated requisite composting and recycling household organic pollutants in 2005 but, bad odors were a problem of the plants. Four composting plants in Taiwan were strained to close due to public disagreements (Houng, 2005).

\subsection{Waste Management in Some Countries}

In some countries, composting rates and food waste management strategies are listed below by help of scientific literature (Wei et al. 2017; Pearson et al. 2015). From 1990 to 2010, approximately 180 mechanical-biological treatment plants were installed in EU to divert biodegraded waste from landfills. MSW composted in EU increased from 8\% to 15\% from 1999 to 2013. In UK, composting rate increased by mandatory targets for landfill tax from 7 to $84 \mathrm{GBP} /$ ton in 1996 to 2016. In 2000, only 0.8 million tons hou sehold waste (3\% of total) was composted, but in 2014 it was 4 million tons (19\%). Food waste collected separately increased over 20 times from 2006 to 2012, to nearly 350,000 tons. In Spain, capacity was increased by 5 million tons through the installation of 50 new MBT plants. MSW composting rate in China decreased from $10 \%$ to less than $2 \%$ in the past 15 years and similar trends may exist in other developing countries. In USA, in 1990, 4.2 million tons of MSW ( $2 \%$ of total) was composted but it was increased to 20.6 million (8.4\%) in 2005 by encourage yard trimmings compost. MSW composting stagnated in the 10 years after 2005. From 1985 to 1995 , landfill tax increased by $177 \%$ but in 2013 it was $\$ 50 /$ ton, only $1.58 \%$ higher. Therefore, no motivation to recycle/compost. In 2013, yard trimmings was 37 , food waste was 37 million tons and only 58\% and 5\% were composted. In Canada, MSW composting facilities in Guelph, Ontario, and Lunenburg, Nova Scotia have shown landfill diversion rates in excess of 70 and $67 \%$, respectively. Therefore, in developing countries it is essential to identify the barriers that impede waste composting and predict developing trends.

\subsection{Composting applications and failures in Turkey}

In the past years, composting plants were built in a few cities in Turkey. Composting applications and reasons of operation failure in Turkey in the past years are seen in Table 1.

Table 1. Composting applications and reasons of failure in Turkey.

\begin{tabular}{|c|c|}
\hline City & Problems \\
\hline $\begin{array}{l}\text { Mersin } \\
(160 \mathrm{t} / \mathrm{h}, \% 50 \text { of city waste, built by a French firm) }\end{array}$ & $\begin{array}{l}\text {-Not considered the local waste characteristics, } \\
\text {-No local material market, } \\
\text {-Using old technology, no spare parts } \\
\text {-No work in rainy weather because the floor is not concrete } \\
\text {-Political reasons, personnel change, etc. } \\
\text {-In winter, compost cannot pass through the screen }\end{array}$ \\
\hline $\begin{array}{l}\text { Antalya } \\
(50 \text { t/day) }\end{array}$ & $\begin{array}{l}\text {-Very high electricity demand-operating cost } \\
\text {-Foreign matter in the compost is also high }\end{array}$ \\
\hline $\begin{array}{l}\text { Izmir } \\
(500 \mathrm{t} / \text { day })\end{array}$ & $\begin{array}{l}\text { - Problems in machines } \\
\text { - High operation cost }\end{array}$ \\
\hline Marmaris & - Only a few days operation \\
\hline $\begin{array}{l}\text { Giresun } \\
(60 \text { t/day) }\end{array}$ & $\begin{array}{l}\text {-Only } 5 \text { years, non-continuous operation } \\
\text {-Compost is given free of charge } \\
\text {-Bad operation, low quality compost } \\
\text {-Consumers, farmers were not happy with this compost } \\
\text {-Especially odor complaints } \\
\text {-No operation due to precipitation in winter conditions } \\
\text {-Separated waste is not well marketed } \\
\text {-Frequent machine problems } \\
\text {-Work of inexperienced technicians }\end{array}$ \\
\hline
\end{tabular}


As seen from the Table 1, composting was planned and built in a few cities. Almost all of these plants were planned by the central authority and mainly built by a company, but as seen, there have been many problems related to design and local conditions as well as the operation. As a result, it is seen that the most important problems are engineering problems and the municipalities do not pay enough attention to this issue.

If we evaluate the situation, it is not easy to say that municipalities in Turkey do not have very effective investments, but in fact they have enough success for infrastructure within the cities where public (voters) directly affected. However, there are some, or even many problems in sanitary landfilling of solid waste or operating the composting plants, or even built and operating wastewater treatment plants because those plant are away of the cities and removal of the waste out of the city is a sufficient service duty for the municipalities. The ministry and municipalities cannot show sufficient success in solving these problems and its organization.

In Table 2, composting plants in Turkey and their capacities are given in the report of the Municipality. However, when the data is analyzed, it is seen that composting data in the Environmental Statics of Turkish Statistical Institute and data of the Municipality's report are different. There are inconsistencies between the data of those agencies.

Table 2. Composting plants in Turkey in recent years (CSB, 2017).

\begin{tabular}{lccc}
\hline PROVINCES & $\begin{array}{c}\text { Waste } \\
\text { capacity } \\
\text { tones/year }\end{array}$ & $\begin{array}{c}\text { Amount of transferred } \\
\text { tones/year }\end{array}$ & $\begin{array}{c}\text { Amount of composted* } \\
\text { tones/year }\end{array}$ \\
\hline Izmir & 127750 & 64499 & 38866 \\
Istanbul & 365000 & 139346 & 71243 \\
Antalya & 54750 & 71348 & 32385 \\
Denizli & 3000 & 544 & 544 \\
\hline
\end{tabular}

In the Table 2, capacity of the facilities is seen as high but actually these values maybe lower. For example, the information about the facility in Istanbul is reported as averagely 20,000 tons/year by the municipality (IBB, 2020).

\subsection{Waste Management in Istanbul and Turkey}

Istanbul city has performed improvement in solid waste management in the last decades and do plans for next years (Kanat et al., 2006; Kanat, 2010). For example, sanitary landfill was built after 1994 and will supply 25 years energy production from landfill gas. Municipal solid waste is rising up to 20,000 tons per day. The city can evaluate only $\% 15$ of the waste, recycle/recover only $\% 4.5$ and landfill of the remaining \%85. An incineration facility, capacity with 3,000 tons/day was planned in 2009 and will be operation in 2021. Also, 100 tons/day biomethanization plant is planned to be in operation in 2024. Then, electricity of about 1.5 million people will be supplied and, landfill will be lower to $\sim \% 50$. Average annual compost production is 19,000 tons/year in a 1,000 ton/day capacity plant. Compost is used in green park areas, but municipality has a sale price of $45 \mathrm{TL} /$ ton (1 US\$ $\$ \sim 5 \mathrm{TL}$ ) in 2018 (ISTAC, 2018).

Ministry of Environment reported that municipal waste generated in Turkey in 2014 was 27.1 million tons (CSB, 2017). Most of the waste, $64 \%$, was disposed of in sanitary landfills and 30\% in open dumping areas, while only $6 \%$ recycled. Same as in other developing countries, the most appropriate and economical waste management methods are required. MSW in 2018 was 30 million tons but it will increase to 33 million tons in 2023. The Ministry planned to reach to $65 \%$ landfill and $35 \%$ recovery in 2023 . In order to reach this target, amount of separated packaging waste $(5.3 \%$ in 2014) was planned to increase to $12 \%$ in 2023 . Biological treatment methods $(0.2 \%$ in 2014$)$ will be increased to $4 \%$. The target for mechanical-biological pre-treatment (MBP) processes $(5.4 \%$ in 2014) is $11 \%$ while landfilling rate $(88.7 \%$ in 2014) will be reduced to $65 \%$ in 2023 (CSB, 2017).

There are 8 biological waste processing facilities in Turkey. Amasya, Aydin, Balıkesir, Canakkale, Denizli and Kutahya provinces have a compost plant (CSB, 2017). Biomethanization plants were built in Kocaeli and Sakarya cities. Furthermore, 6 mechanicalbiological pre-treatment and recycling facilities are in operation, 2 compost and bioprocessing plant in Istanbul, and 4 biomethanization plant in Ankara, Adana and Samsun cities.

The Ministry planned to reach to $65 \%$ landfill and $35 \%$ recovery in 2023 . For this purpose; packaging waste, $5.3 \%$ separately collected at the source in 2014 will be planned to reach $12 \%$ in 2023. Biological methods for municipal waste, which is $0.2 \%$ in 2014 , will be raised to $4 \%$ in 2023 . Rate of the MBP processes, $5.4 \%$ in 2014 , will be increased to $11 \%$ in 2023 . Landfilling rate of municipal waste, which was $88.7 \%$ in 2014, will be reduced to $65 \%$ in 2023 (CSB, 2017). 
Recently, Ministry of Environment activated a National "Zero waste" plan which will be firstly applied in governmental agencies and later, in shopping malls, hospitals, schools, universities and large workplaces (> 1000 employees) until 2023 (anniversary of Turkish Republic). It is applied in Ministry's Main Building for 3 months and reported that 45 tons paper, 11 tons plastic, 2.5 tons glass, 1 ton metal and in total approximately 60 tons waste was a gain in the economy. There are only few details about organic material composting. JK6200 compost machine (Sweden) is used to produce $180-200 \mathrm{~kg}$ compost from $1000 \mathrm{~kg}$ waste in 30 days.

\subsection{Vermicomposting}

Vermicomposting an environmentally-friendly process to transform organic materials into organic manure by earthworms (Nath and Singh 2016). Vermicompost contain nutrient-rich natural organics and has several positive impacts on plant growth (Xiao et al., 2017). The most important aspect of compost produced by earthworms is that it is all organic. There are no harmful chemicals and it does not need to be mixed with anything. Vermicomposting produces a product that is naturally designed to benefit plants in several different ways. The most significant benefit is that the nutrients in earthworm compost are very easily absorbed by the roots of plants. Unlike chemical fertilizers, vermicompost is not easily flushed from the soil because of the worm mucus that it contains. Plants have longer to obtain the nutrients and get the maximum benefit (Nath and Singh 2016).

Chemical fertilizers bombard plants with huge amounts of nutrients that are going to drain by and eventually be washed out of the soil by the rain. The chemicals can get into the aquifers and contaminate drinking water. This can be avoided by using a compost which is lower in nutrient content but which does not get washed out of the soil. The nutrients are held in place and released slowly so that the plants receive what they need over a prolonged period. Using earthworms creates a product that is natural and behaves naturally. The cycle of regularly over-dosing the soil is broken. Plant health is promoted by long-term exposure to nutrients and the soil condition will continue to improve (Xiao et al., 2017).

Vermicomposting is also increasing in Turkey. It is not easy to say that it is correct or not, because there is no technical data but in media news, people say that they have a good amount/sufficient money by vermicomposting (small or larger scale-up to 2-3000 tons/month). Those plants are operated mainly by using organic (agricultural) waste, not mixed municipal waste. The number of vermicomposting companies and also personal activities has increased in recent years in the country to benefit the output of this process.

\subsection{Recommendations for Waste Management and Composting}

Some recommendations for waste management and composting can be done by help of mentioned information. In Table 3, some suggestions are listed for a successful composting It is advised do not or do if it is possible to apply those recommendations. Also in Table 3, some observed problems related to composting activities in Turkey are listed. As seen in the table, there are some common problems in Turkey, similar to other developing countries.

Table 3. Observed problems related to composting activities.

Factors for a successful composting

1. Separated organic collection system is needed,

2. Big plants should not be constructed before getting experience in pilot systems,

3. Automatic installations should be well examined and, if possible, not be preferred in terms of operating and maintenance costs

4. It should not be misunderstood that the compost product is the material that can be used and sold very easily

5. Optimal technology choice should be investigated

6. Very good planning should be done, not believe in magic technologies like enzyme or special bacteria species

7. Market identification is a prerequisite for successful strategies and it is also important for long term operation of composting plant

8. Municipalities should ensure action plans, education and training of the personnel

9. Political will and continuity of the policy is also important for sustainable activities.

Some observed problems related to composting activities in Turkey

1. The Ministry is unable to provide adequate, sufficient coordination

2. The municipalities are inexperienced and irrelevant/uninterested (both in planning and operation phases of the plants)

3. The municipalities, for various reasons, hastily prepared plans, politics, etc. Do not get enough knowledge (or cannot) from the other experienced institutions.

4. There is very little cooperation between the universities and public/private institutions.

5. Composting activities should have support and great involvement from the governmental agencies and private sector.

6. Turkish farmers should be educated for benefits of compost and how to use it as a fertilizer and/or soil conditioner

7. Good cost benefit analyze is a must before deciding to construct composting plants,

8. Those activities have weak economic performance and economic support policy is required for successful results. 


\section{Conclusions}

Municipal solid waste is an unavoidable waste, especially in the big cities, with high population increase, urbanization and socioeconomic developments. Waste management is a serious problem for local and national authorities. Wastes are not only contain high amount of organics but also most heterogeneous kind of refuse. Appropriate waste management is crucial for environmental sytem and human health. Solid waste management is a multi-dimensional issue. It involves a large number of different stakeholders, which play a role in shaping the system. Municipal waste management technologies and strategies in Turkey was based on the objectives of the Waste Landfill Regulation and Packaging Wastes Control Regulation. In the recent case, there are some biological waste treatment processing facilities built in Turkey. Additionally, there are some mechanical-biological pre-treatment and recycling process facilities where mixed municipal waste is treated. In the management strategies, the waste formed in 2023 was targeted to $65 \%$ landfilled and $35 \%$ recovery with some methods.

Composting represents one of cleaner technologies in diverting organic pollutants from landfill. Organics generally includes 40$70 \%$ of MSW. Management of the organic fraction of the solid waste has getting increasing attention in recent years. It is also important to separate organic waste by either source separation or centralized mechanical separation for further treatment such as composting. However, it is seen that composting is still not a common method in Turkey, similar to the cities of many countries, due to some reasons. When administrative and technical factors are evaluated, waste transferring to landfill and biogas recovery is currently the best, easiest and economical method in the country. Moreover, National Zero Waste activities in Turkey and Istanbul City are still in the beginning phase and may need long time to have better results.

\section{References}

CSB, (2017). Ministry of Environment, "Annual Report" webpage available: webdosya.csb.gov.tr, April 2018. Ministry of Environment (CSB), webpage available at: http://sifiratik.csb.gov.tr [Accessed April 21, 2018 ].

EU, 2008. Directive 2008/98/EC of The European Parliament And of The Council on Waste and Repealing Certain Directives. Official Journal of the European Union, L312, 3-30.

Gajalakshmi, S. \& Abbasi, S.A. (2002). Effect of the application of water hyacinth compost/vermicompost on the growth and flowering of Crossandra undulaefolia and on several vegetables. Bioresour. Technol., 85, 197-199.

Houng, H. (2005). "Policies and Measures of Waste Disposal and Treatment in Taiwan." In book: Towards Zero Waste Society. New Management Policies for Solid Waste Disposal in Chinese Taipei. pp: 69-143. Available at: https://www.pecc.org/resources/infrastructure-1/1246-towards-zero-waste-society [Accessed May 21,2019]

ISTAC, (2018). webpage available at: http://www.istac.istanbul, [Accessed Apr 10, 2018].

IBB (2020). webpage available at: https://atikyonetimi.ibb.istanbul/hizmetlerimiz/kompost-ce-geri-kazanim-tesisi, [Accessed Feb 10, 2020].

Kanat, G., A. Demir, B. Ozkaya, M.S. Bilgili, (2006). "Addressing the operational problems in a composting and recycling plant", Waste Management, 26 (12), 1384-1391.

Kanat, G. (2010). "Municipal solid-waste management in Istanbul”, Waste Management, 30, 1737-1745

Laurent, A., Bakas, I., Clavreul, J., Bernstad, A., Niero, M., Gentil, E., Hauschild, M.Z. \& Christensen, T.H. (2014). Review of LCA studies of solidwaste management systems - part I: lessons learned and perspectives. Waste Manage., 34, 573-588.

Logsdon S.D., Sauer P.A., Shipitalo M.J. (2017). Compost improves urban soil and water quality. J. Water Resour. Protect., 9, 345357.

Meng X., Liu B., Zhang H., Wu J., Yuan X. \& Cui Z. (2019). Co-composting of the biogas residues and spent mushroom substrate: Physicochemical properties and maturity assessment. Bioresource Technol., 276, 281-287

Mohammadshirazi F., McLaughlin R.A., Heitman J.L. \& Brown V.K. (2017). A multi-year study of tillage and amendment effects on compacted soils. J. Environ. Manag., 203, 533-541

Mohee, R. \& Soobhany, N. (2014). Comparison of heavy metals content in compost against vermicompost of organic solid waste: past and present. Resour Conserv Recycl., 92, 206-213.

Nath, K. \& Singh, K. (2016). Analysis of different nutrient status of liquid biofertilizer of different combinations of buffalo dung with gram bran and water hyacinth through vermicomposting by Eisenia fetida. Environ Dev Sustain., 18, 645-656.

Pearson, C., Littlewood, E., Douglas, P., Robertson, S., Gant, T.W. \& Hansell, A.L. (2015). Exposures and health outcomes in relation to bioaerosol emissions fromcomposting facilities: a systematic review of occupational and communitystudies. J. Toxicol. Environ. Health B Crit. Rev., 18(1), 43-69.

TUIK (2020). Environmental Statics, The Turkish Statistical Institute webpage available

at: https://biruni.tuik.gov.tr/medas/?kn=119\&locale=tr, [Accessed Feb 10, 2020].

Wang, T., Wang, S., Zhong, X., Sun, Z., Huang, Y., Tan, L., Tang, Y. \& Kid, K.. (2017). Converting digested residue eluted from dry anaerobic digestion of distilled grain waste into value-added fertilizer by aerobic composting. J. Cleaner Prod., 166, $530-536$.

Wei, Y., Li, J., Shi, D., Liu, G., Zhao, Y. \& Shimaoka, T. (2017). Environmental challenges impeding the composting of biodegradable municipal solid waste: A critical review. Resour Conserv Recycl., 122, 51-65.

Xiao R., Awasthi M.K., Li R., Park J., Pensky S.M., Wang Q., Wang, J.J. \& Zhang, Z. (2017). Recent developments in biochar utilization as an additive in organic solid waste composting: a review. Bioresour. Technol., 246, 200-213. 